\title{
Seasonal monitoring of Hida salamander Hynobius kimurae using environmental DNA with a genus-specific primer set
}

\author{
Toshiaki Jo ${ }^{1,2}$, Sei Tomita1, Yukihiro Kohmatsu ${ }^{3}$, Maslin Osathanunkul ${ }^{4,5}$, \\ Atushi Ushimaru1, Toshifumi Minamoto ${ }^{1, *}$ \\ ${ }^{1}$ Graduate School of Human Development and Environment, Kobe University, 3-11, Tsurukabuto, Nada-ku, Kobe City, \\ Hyogo 657-8501, Japan \\ ${ }^{2}$ Research Fellow of Japan Society for the Promotion of Science, 5-3-1 Kojimachi, Chiyoda-ku, Tokyo 102-0083, Japan \\ ${ }^{3}$ Ritsumeikan-Global Innovation Research Organization, 56-1, Tojiin-Kitamachi, Kita-ku, Kyoto City, Kyoto 603-8577, Japan \\ ${ }^{4}$ Department of Biology, Faculty of Science, Chiang Mai University, Chiang Mai 50200, Thailand \\ ${ }^{5}$ Center of Excellence in Bioresources for Agriculture, Industry and Medicine, Chiang Mai University, Chiang Mai 50200, Thailand
}

\begin{abstract}
The diversity and the abundance of amphibians have dramatically declined globally over the past 30 years, and the monitoring and conservation of their habitats is essential. However, traditional methods such as bait trapping and mark-recapture are costly, and morphological identification usually requires a high level of taxonomic expertise. Here, seasonal surveillances of Hida salamander Hynobius kimurae were performed by means of environmental DNA (eDNA) analysis with Hynobius-specific primers and a species-specific TaqMan probe. Water sampling and visual surveys were conducted seasonally in a stream in Kyoto Prefecture, Japan. Detection rates of eDNA were then calculated by real-time PCR, and eDNA site occupancy probability was estimated by multi-scale occupancy modeling. The eDNA-based detection rate of Hida salamander was $76.7 \%$, whereas the visual survey-based detection rate was $23.3 \%$, and target eDNA was detected at almost all sites where the presence of target species was visually confirmed. Moreover, factors relating to the site- and sample-level occurrence probabilities of the target eDNA differed depending on the developmental stage of the target species. Our findings support previous studies showing that eDNA analysis enables an effective assessment of amphibian distributions without damaging the organisms or their habitat, and we compare for the first time the site occupancy probability of amphibian eDNA throughout the life cycle of an amphibian species. The present study contributes to the development of eDNA analysis as a tool for understanding the distribution and seasonal activity of amphibian species and will thus aid in the planning of conservation measures and habitat restoration for these species.
\end{abstract}

KEY WORDS: Amphibian - Conservation management - Environmental DNA (eDNA) · Hynobius kimurae $\cdot$ Real-time PCR $\cdot$ Spatiotemporal ecology

\section{INTRODUCTION}

The decline and the extinction of amphibians are issues of global conservation concern (Young et al. 2001, Beebee \& Griffiths 2005, Ceballos et al. 2015).

${ }^{*}$ Corresponding author: minamoto@people.kobe-u.ac.jp
They are mainly caused by habitat destruction owing to land-use changes (Houlahan et al. 2000, Hels \& Buchwald 2001), biological invasions (Kats \& Ferrer 2003), and infectious diseases such as chytridiomycosis and Ranavirus (Berger et al. 1998, Daszak et al.

(C) The authors 2020. Open Access under Creative Commons by Attribution Licence. Use, distribution and reproduction are unrestricted. Authors and original publication must be credited. 
2003). There is an urgent need to monitor remaining habitats of amphibians; however, traditional methods (e.g. visual surveys, bait trap, mark-recapture, telemetry) require substantial effort and costs, and could be invasive and destructive for organisms and their habitats (Darling \& Mahon 2011). In addition, morphological identifications usually require a lot of taxonomic expertise, especially for eggs and larvae (Gotelli \& Colwell 2001, Hopkins \& Freckleton 2002).

As a novel monitoring method to overcome such limitations, environmental DNA (eDNA) analysis has been developed (Minamoto et al. 2012, Bohmann et al. 2014, Deiner et al. 2017). Organisms likely shed their DNA in the forms of mucus, feces, and gametes, which are collectively termed eDNA (Taberlet et al. 2012, Barnes \& Turner 2016). The detection of eDNA in water samples via PCR does not require damaging organisms and their habitats, and can have more highly sensitive detection capabilities than traditional methods (Taberlet et al. 2012, Thomsen \& Willerslev 2015). Since the primary inception of eDNA analysis for macro-organisms in 2008 , showing the positive correlation between the eDNA detectability of American bullfrog Lithobates catesbeianus and species abundance in ponds (Ficetola et al. 2008), several studies have monitored the distribution of amphibians via eDNA and have shown its high sensitivity and ease of use (Dejean et al. 2012, Fukumoto et al. 2015, Spear et al. 2015, Pitt et al. 2017, Takahashi et al. 2018, Wineland et al. 2019).

In Japan, the family Hynobiidae comprises 41 species: one species from Salamandrella, 34 species from Hynobius, and 6 species from Onychodactylus (Herpetological Society of Japan 2019). The genus Hynobius includes diverse locally endemic species, most of which are severely threatened by land developments and invasive predators, and are thus listed as critically endangered to near threatened in the National Red List (Ministry of the Environment, Japan 2018). Although a few studies have conducted eDNA-based monitoring of amphibians in Japan (Fukumoto et al. 2015, Katano et al. 2017, Iwai et al. 2019), no study has targeted Hynobius species except for that of Sakai et al. (2019), which surveyed the distribution of the endangered Yamato salamander $H$. vandenburghi.

It would be desirable to monitor the distribution of all Hynobius species using eDNA analysis, although it is labor- and time-consuming to individually develop the specific eDNA assay for each species. On the other hand, eDNA metabarcoding via nextgeneration sequencing enables multiple species detection in a single analysis; however, this approach sometimes cannot distinguish closely related species depending on the target locus (Bylemans et al. 2018). As an alternative strategy, the combination of the genus-specific primers and a species-specific TaqMan probe may reduce the overall effort and cost for assay development. In addition, the use of fluorescently labeled oligonucleotides as the probe increases the specificity and sensitivity of the assay (Wilcox et al. 2013, Fukumoto et al. 2015, Wozney \& Wilson 2017).

Here, we targeted Hida salamander Hynobius kimurae living in lotic freshwater environments in Japan (Hayase \& Yamane 1989, Matsui et al. 2009) as a model species (Fig. 1). The present study demonstrated whether the combined use of genus-specific primers and a species-specific probe was a viable option for eDNA detection in the natural environment, and conducted seasonal monitoring of Hida salamander distribution in a stream using the primer/ probe set. Amphibians, including our model species, often reproduce in a shallow water body; larvae grow in water with branchial respiration, and after metamorphosis, adults in the non-breeding period live on the humid forest floor and underground (Hayase \&

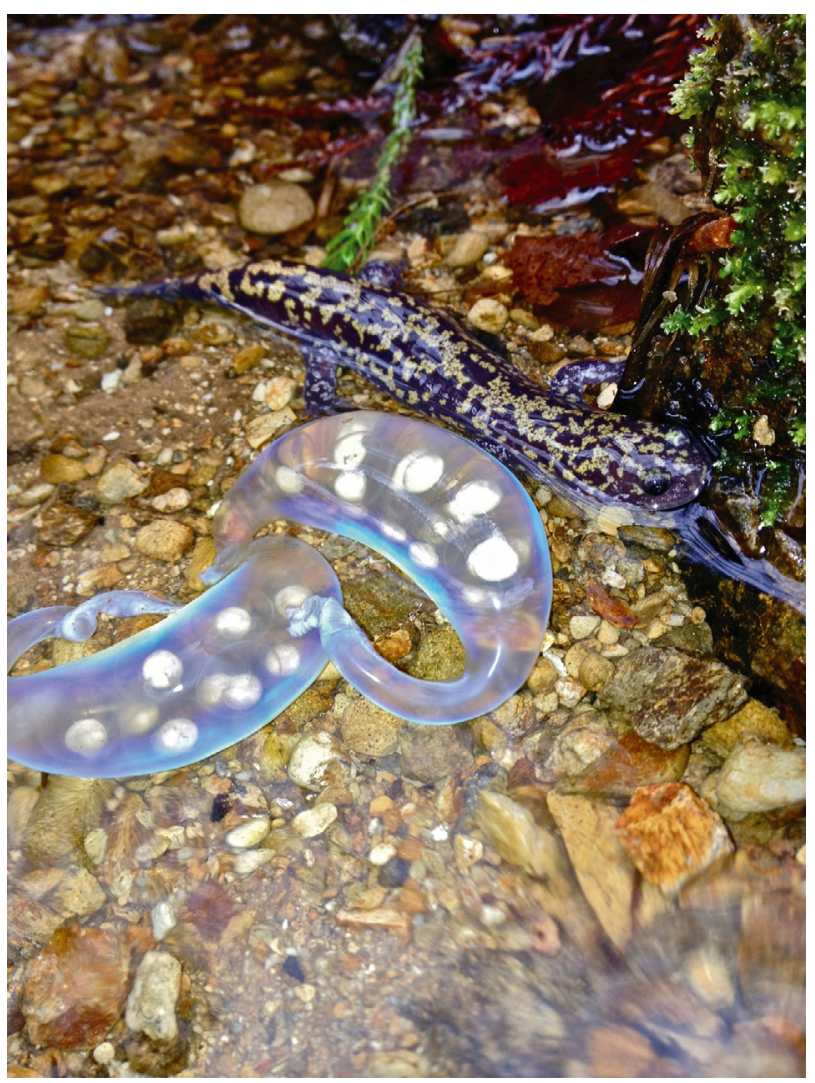

Fig. 1. Adult Hida salamander Hynobius kimurae and its eggs 
Yamane 1989, Dodd 2010, Wells 2010). However, these descriptions are based upon very limited observations. Although the Hida salamander is listed as near threatened in the National Red List (Ministry of the Environment, Japan 2019) and as critically endangered in the Red Data books of some prefectures in Japan (http://jpnrdb.com/search.php?mode $=$ map $\& q=03010010017$ ), in common with other salamanders and amphibians, the spatiotemporal ecology and life history of this species have yet to be sufficiently established. In addition, it has been reported that in the Kyoto Prefecture, populations of Hida salamander have tended to decline owing to the loss of lotic habitat due to anthropogenic activities (Red Data Book of Kyoto Prefecture 2015). In this study, we applied our eDNA assay to evaluate whether it can be used to detect seasonal trends in the finescale occupancy of Hida salamanders, which have been indicated using traditional methods. Moreover, the site occupancy probabilities of Hida salamander eDNA were estimated (Dorazio \& Erickson 2018) during reproduction and before and after incubation to account for false-negative errors in eDNA detection and environmental factors that could introduce such errors.

\section{MATERIALS AND METHODS}

\subsection{Development of the assay for Hida salamander eDNA}

Genus-specific primers that amplify a 290 bp DNA fragment of the mitochondrial $12 \mathrm{~S}$ region from a Hynobius species in Japan were taken from Sakai et al. (2019) (Table 1). Thus, a TaqMan probe that specifically hybridized DNA from the Hida salamander was newly designed. We obtained all sequences of the target (accession number: MH287432.1) and of closely related species ( $H$. hidamontanus [AY915983.1], H. naevius [AB201658.1], and H. yatsui [AB201667.1]) from the National Center for Biotechnol- ogy Information (NCBI), and then designed a TaqMan probe using Primer Express 3.0 (Thermo Fisher Scientific) with default settings (probe length: 13 to 25 bases; $T_{\mathrm{m}}$ : 68 to $70^{\circ} \mathrm{C}_{\text {; }} \mathrm{GC}$ content: 30 to $80 \%$; $5^{\prime}$ end terminating in a base other than G). We confirmed in silico specificity of the designed probe by alignment and comparison of the sequence of the target species with those of related species using eBioX (www.ebioinformatics.org/ebiox/).

The in vitro specificity of the assay was then assessed using the StepOnePlus Real-Time PCR system (Applied Biosystems). Each $20 \mu \mathrm{l}$ of TaqMan reaction contained 100,10, or 1 pg of total DNA obtained from 1 Hida salamander individual and 2 Yamato salamander $H$. vandenburghi individuals (Sakai et al. 2019), which are potentially sympatric related species in the studied area [Matsui et al. 2019]), a final concentration of $900 \mathrm{nM}$ of forward and reverse primers, $125 \mathrm{nM}$ of TaqMan probe, and $0.1 \mathrm{U}$ of AmpErase Uracil N-Glycosylase (Thermo Fisher Scientific) in a 1× TaqMan Environmental Master Mix 2.0 (Thermo Fisher Scientific). The thermal conditions used for PCR amplification were as follows: $2 \mathrm{~min}$ at $50^{\circ} \mathrm{C}$ and $10 \mathrm{~min}$ at $95^{\circ} \mathrm{C}$, followed by 55 cycles of $15 \mathrm{~s}$ at $95^{\circ} \mathrm{C}$ and $1 \mathrm{~min}$ at $60^{\circ} \mathrm{C}$. As a negative control, we simultaneously amplified PCR mixtures containing $1 \mu \mathrm{l}$ of pure water in place of extracted DNA.

In addition, the sensitivity of the assay was checked by the StepOnePlus Real-Time PCR system. Each $20 \mu \mathrm{l}$ of TaqMan reaction contained a 10-fold serial dilution $\left(10^{2}-10^{-4} \mathrm{pg}\right)$ of DNA extracted from the exuviae of Hida salamander, a final concentration of $900 \mathrm{nM}$ of forward and reverse primers, $125 \mathrm{nM}$ of TaqMan probe, and $0.1 \mathrm{U}$ of AmpErase Uracil N-Glycosylase in a 1× TaqMan Environmental Master Mix 2.0. The thermal conditions used for PCR amplification were the same as those described above. A $2 \mu \mathrm{l}$ volume of pure water in place of extracted DNA was simultaneously analyzed as a negative control. All the PCRs for the template DNA and negative control were performed in triplicate.

Table 1. Primer/probe set used in this study. $T_{\mathrm{m}}$ : melting temperature

\begin{tabular}{|llcccc|}
\hline ID & Sequence (5'-3') & $\begin{array}{c}\text { Length } \\
(\mathrm{bp})\end{array}$ & $\begin{array}{c}T_{\mathrm{m}} \\
\left({ }^{\circ} \mathrm{C}\right)\end{array}$ & $\begin{array}{c}\text { Amplicon } \\
\text { size (bp) }\end{array}$ & Reference \\
\hline Hynobius_12S_F1 & TTA ATA AAA ACG GCC TAA AGC GTG & 24 & 58.61 & 290 & Sakai et al. (2019) \\
Hynobius_12S_R1 & TCA ATT ATA GAA CAG GCT CCT CTA GGG & 27 & 61.40 & Sakai et al. (2019) \\
Hida_12S_P & [FAM]-CCT TAA ACT TTG GAG CCT ACC CGC & 27 & 67.24 & Present study \\
& CTG-[TAMRA] & & & & \\
\hline
\end{tabular}




\subsection{Field survey and water sampling}

Seasonal surveillances were conducted in a stream in Kyoto Prefecture, Japan (349 $\left.97^{\prime} \mathrm{N}, 135^{\circ} 64^{\prime} \mathrm{E}\right)$, from February to October 2016 (Fig. 2). Most Hynobius species show habitat segregation, and 2 species rarely share their breeding habitats. In the studied stream, the Hida salamander and related species mentioned above do not share their breeding habitats. Ten sampling sites were selected in the mainstream from the headwater to approximately $2 \mathrm{~km}$ downstream (Stns 1 to 7 ) as well as in the tributaries (Stns 8 to 10), at intervals of $\sim 200 \mathrm{~m}$. Tributaries (Stns 8,9 , and 10) are connected to the mainstream between Stns 1 and 2, 2 and 3, and 3 and 4. A single 11 water sample was collected from each site using a plastic bottle in sequence from downstream to upstream, and benzalkonium chloride (BAC) was added to the water sample (for a final concentration of $0.01 \%$ ) to suppress DNA degradation (Yamanaka et al. 2017). Disposable gloves were put on during water sampling and replaced at each sampling site. When collecting the water samples, the environmental parameters (water temperature, $\mathrm{pH}$, and electrical

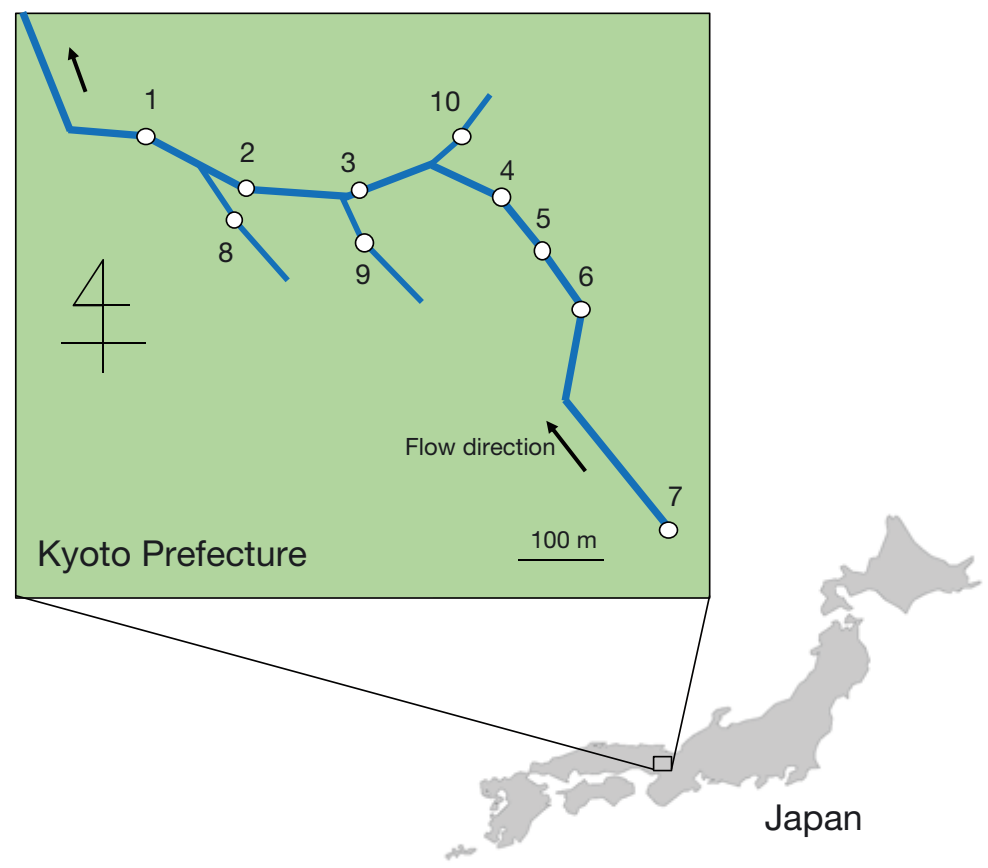

Fig. 2. Schematic map of all sampling sites in the surveyed stream in Kyoto Prefecture, Japan. The flow direction of the river is from Stn 7 (the headwater, bottom right) to Stn 1 (top left). We collected water samples from the mainstream (Stns 1 to 7 ) on every sampling day, and from the tributary (Stns 8 to 10) from 28 April 2016. Note that the detailed location of the sampling river is not disclosed because of the rarity and conservation importance of our target species conductivity [EC]) were measured using a Hanna Combo 2 (HI 98130; Hanna Instruments). In addition, the species occurrences (adults, larvae, or eggs) were recorded when their presence was visually confirmed (Table S1 in Supplement 1 at www.int-res.com/ articles/suppl/n043p341_supp1.xlsx), which was performed by 2 to 4 people and took 10 to $15 \mathrm{~min}$ per site including flipping rocks. Although it would have been preferable to undertake more exhaustive surveys to accurately assess the presence/absence of salamanders, we determined that visual surveys would suffice, as our primary objective was to establish differences in species detectability between methods when the survey efforts in the field are comparable. The presence of the species at a given site in the mainstream included the presence between the site and a neighboring site upstream. However, because we did not set multiple sampling sites in each tributary, the presence of the species at a given site in the tributary included the presence within approximately $10 \mathrm{~m}$ upstream. Field surveys, which included water sampling and visual surveys, took 3 to $5 \mathrm{~h}$ on each sampling date and 10 to $30 \mathrm{~min}$ at each sampling site. Throughout the course of the surveys, we detected no other species of salamander in the studied stream.

After being transported immediately to the laboratory, water samples were filtered through a $47 \mathrm{~mm}$ diameter glass microfiber $\mathrm{GF} / \mathrm{F}$ filter (nominal pore size $0.7 \mu \mathrm{m}$; GE Healthcare Life Science). Each water sample was filtered through $2 \mathrm{GF} / \mathrm{F}$ filters (i.e. $500 \mathrm{ml} \times 2$ filters). On each sampling day, 11 of distilled water was filtered as a negative control to assess the potential for contamination of target eDNA during and after water filtration. Before and after every use, all sampling bottles and filtering devices (i.e. filter funnels [Magnetic Filter Funnel, $500 \mathrm{ml}$ capacity; Pall Corporation], 11 beakers, and tweezers) were bleached with $0.1 \%$ sodium hypochlorite solution for at least 5 min (Yamanaka et al. 2017). All filter samples were stored at $-20^{\circ} \mathrm{C}$ until DNA extraction.

\subsection{DNA extraction and real-time PCR}

Total DNA on GF/F filters was extracted by using a DNeasy Blood and Tissue Kit (Qiagen, Hilden, Germany) according to the method described in a previous study 
(Uchii et al. 2016) (Text S1 in Supplement 2 at www.int-res.com/articles/suppl/n043p341_supp2.pdf), where the 2 filters from each water sample were combined. The presence of Hida salamander eDNA in water samples was evaluated by the StepOnePlus Real-Time PCR system. Each $20 \mu$ l TaqMan reaction contained $2 \mu \mathrm{l}$ of template DNA, a final concentration of $900 \mathrm{nM}$ of forward and reverse primers, $125 \mathrm{nM}$ of TaqMan probe, and $0.1 \mathrm{U}$ of AmpErase Uracil N-Glycosylase in a 1× TaqMan Environmental Master Mix 2.0. Thermal conditions of the PCR were the same as above. We simultaneously analyzed $10 \mathrm{pg}$ of exuviae-extracted DNA from the target species and $2 \mu \mathrm{l}$ of pure water as positive and negative controls, respectively. All the PCRs for eDNA extracts, positive controls, and negative controls were performed in triplicate. If any triplicate was amplified by PCR, we considered it as the detection of target eDNA in the sample. A randomly selected group of the positive eDNA samples $(\mathrm{n}=22)$, corresponding to $22.2 \%$ of positive eDNA samples, was commercially Sangersequenced using a 3130xl Genetic Analyzer (Applied Biosystems) and BigDye Terminator v3.1 (Thermo Fisher Scientific).

Targeting 3 water samples with high EC in the study $\left(>0.1 \mathrm{mS} \mathrm{cm}^{-1}\right.$; Table S1), we checked PCR inhibition using a spiking experiment. We spiked $10 \mathrm{pg}$ of exuviae-extracted DNA from target species in each water sample (spiking samples) or pure water (control samples). Real-time PCR platform, TaqMan reaction, and thermal conditions were the same as above, and all the PCRs were performed in triplicate. We then calculated $\Delta C_{\mathrm{t}}$ for each water sample, which was defined as the difference in cycle threshold $\left(C_{\mathrm{t}}\right)$ values of each spiking sample from that of the control samples.

\subsection{Statistical analysis}

At first, based on the visual survey (Table S1), each sampling day was assigned to 4 periods: reproductive (5 February to 15 March), egg (11 April to 23 May), larval (2 June to 8 August), and post-larval (only 13 October). Detection rates (\%) of target species were calculated for eDNA analysis (i.e. the proportion of the number of positive PCR samples relative to that of all water samples) and visual surveys (i.e. the proportion of visual surveys in which the target species was detected relative to the total number of visual surveys) overall and for each period.

Moreover, using multi-scale site occupancy modeling with the Bayesian Monte Carlo Markov chain
(MCMC) algorithm, the site occupancy probability of Hida salamander eDNA was estimated for each period. The occupancy probability of target eDNA was modelled using the $\mathrm{R}$ package 'EDNAOCCUPANCY' (Dorazio \& Erickson 2018) in the statistical software R version 3.6.1 (R Core Team 2019). Even if a target species is present in a stream, the corresponding eDNA may not necessarily be detected owing to the loss, degradation, or contamination at different stages of eDNA analysis (e.g. water sampling, DNA extraction, and PCR). This approach allows us to estimate eDNA occurrence and detection probabilities, not the occurrence and detection probabilities of the salamander, taking the imperfect detection with false negatives into account. In addition, it can evaluate various biotic and abiotic factors that may affect probabilities at 3 hierarchical levels: $\Psi$ (site level; probability of target eDNA occurrence at a given sampling site), $\theta$ (water sample level; conditional probability of target eDNA occurrence in each sample of a given site, given that target eDNA was present at the site), and $\rho$ (PCR replicate level; conditional probability of target eDNA detection in each PCR replicate of a given eDNA sample, given that target eDNA was present in the sample) (Schmidt et al. 2013, Chen \& Ficetola 2019).

In the modeling, the presence of target species by visual surveys, water temperature, $\mathrm{pH}$, and $\mathrm{EC}$ were included in the site-level probability $\Psi$, given that (1) more target eDNA can be detected at the site with the presence of species by observation, (2) water temperature and $\mathrm{pH}$ can influence the physiology and reproductive behavior of salamanders (Sadinski \& Dunson 1992, Horne \& Dunson 1994), and (3) high EC indicating eutrophication may negatively affect the species abundance (Pitt et al. 2017). Water temperature and $\mathrm{pH}$ were included in the sample-level probability $\theta$, given that moderately higher temperature and lower $\mathrm{pH}$ may decrease eDNA persistence (Strickler et al. 2015, Jo et al. 2019). None of the factors were included in the PCR replicate-level probability $\rho$. Although a high EC could inhibit PCR amplification, the EC values measured during the course of the present study ranged from 0.00 to $0.12 \mathrm{mS} \mathrm{cm}^{-1}$ (Table S1), and Environmental Master Mix is known to be a reagent tolerant to PCR inhibitors (Doi et al. 2015, Jane et al. 2015). Actually, no substantial inhibition was confirmed in water samples with high EC (see Results). The mean values of water temperature, $\mathrm{pH}, \mathrm{EC}$, and the presence of species by observation were calculated for all sampling events during each period, and were used for the modeling. The dataset for the post-larval period was excluded from the 
occupancy modeling because it is known that no Hida salamanders are found in the stream after October, except for those engaged in reproduction, and indeed, we detected no target eDNA at any sites during this period. According to Dorazio \& Erickson (2018), 10000 iterations of the MCMC algorithm were run per model and burn-in was set at 1000 to discard the initial transient region of the chain to obtain precise parameter estimates. The model selection was performed based on the widely applicable information criterion (WAIC), which was suitable for model selection in the Bayesian estimation (Watanabe 2010). A model with the smallest WAIC value was adopted as the most supported model for each period.

\section{RESULTS}

\subsection{Development of the assay for Hida salamander eDNA}

A TaqMan probe specifically hybridizing Hida salamander DNA was developed (Table 1). The designed probe possessed at least 2 nt of mismatches against the sequences of related species (Fig. S1 in Supplement 2). An in vitro specificity check revealed PCR amplification curves for all concentrations of total DNA obtained from Hida salamander (100 pg: $C_{\mathrm{t}}=28.9 ; 10 \mathrm{pg}: C_{\mathrm{t}}=32.3 ; 1 \mathrm{pg}: C_{\mathrm{t}}=35.9$ ), whereas no amplification curves were obtained for Yamato salamander DNA or the PCR negative control, thereby confirming the species-specificity of the assay. In addition, the in vitro sensitivity check showed that although the developed assay amplified
$10^{2}$ to $10^{-1} \mathrm{pg}$ of exuviae-extracted DNA in triplicate, no DNA within the range $10^{-2}$ to $10^{-4}$ pg was amplified. Thus, the limit of detection (LOD) of the assay was $0.1 \mathrm{pg}$ per PCR reaction (Table S2 in Supplement 1). The slope, $y$-intercept, $\mathrm{R}^{2}$ value, and PCR efficiency of the assay were -3.866, 34.985, 0.981, and $81.406 \%$, respectively.

\subsection{Field survey}

Out of 129 water samples in total, Hida salamander eDNA was detected in 99 samples, which resulted in a $76.7 \%$ overall eDNA detection rate (Fig. 3, Table 2a). Furthermore, eDNA detection rates in the reproductive, egg, larval, and post-larval periods were $94.3 \%$ (33/35 samples), $72.7 \%$ (32/44 samples), $85.0 \%$ (34/40 samples), and $0.0 \%$ (0/10 samples), respectively (Table $2 \mathrm{~A}$ ). In contrast, the presence of the target species was visually confirmed 30 times in total (i.e. overall detection rate by visual surveys was $23.3 \%$ ) (Fig. 3, Table 2B). Target eDNA was detected at almost all the sites where the presence of species was visually confirmed (Fig. 3; Table S3 in Supplement 1). $C_{\mathrm{t}}$ values of all eDNA samples from the realtime PCR experiments are shown in Table S4 (Supplement 1). All of the PCR-positive eDNA samples had $C_{\mathrm{t}}$ values of less than 50, and we confirmed that no filtration or PCR negative controls showed amplification, thereby indicating that there was no contamination of target eDNA during any of the experimental steps (sampling, filtration, DNA extraction, and real-time PCR). Using Nucleotide BLAST in NCBI, we confirmed that all sequences of eDNA samples perfectly matched the Hida salamander

Table 2. Results of the (A) eDNA- and (B) visual survey-based detection rates of Hida salamander in the 4 different developmental periods. In $\mathrm{A}, \mathrm{N}$ is the number of water samples and PCR-positive samples. In $\mathrm{B}, \mathrm{N}$ is the number of total visual surveys and the presence of target species by visual surveys. Rate is the quotient of them. The overall PCR-positive rates of target eDNA in each period are in bold

\begin{tabular}{|c|c|c|c|c|c|c|c|c|c|c|}
\hline & \multicolumn{2}{|c|}{$\begin{array}{c}\text { Overall } \\
\text { (3 Feb-13 Oct) }\end{array}$} & \multicolumn{2}{|c|}{$\begin{array}{c}\text { Reproductive } \\
\text { (3 Feb 3-15 Mar) }\end{array}$} & \multicolumn{2}{|c|}{$\begin{array}{c}\text { Egg } \\
\text { (11 Apr-23 May) }\end{array}$} & \multicolumn{2}{|c|}{$\begin{array}{c}\text { Larval } \\
\text { (2 Jun-8 Aug) }\end{array}$} & \multicolumn{2}{|c|}{$\begin{array}{c}\text { Post-larval } \\
\text { (13 Oct) }\end{array}$} \\
\hline & $\mathrm{N}$ & Rate (\%) & $\mathrm{N}$ & Rate $(\%)$ & $\mathrm{N}$ & Rate $(\%)$ & $\mathrm{N}$ & Rate $(\%)$ & $\mathrm{N}$ & Rate (\%) \\
\hline \multicolumn{11}{|c|}{ (A) eDNA-based detectability } \\
\hline Water sample & 129 & & 35 & & 44 & & 40 & & 10 & \\
\hline PCR positive & 99 & 76.7 & 33 & 94.3 & 32 & 72.7 & 34 & 85.0 & 0 & 0.0 \\
\hline $1 / 3$ positive & 14 & 10.9 & 4 & 11.4 & 7 & 15.9 & 3 & 7.5 & 0 & 0.0 \\
\hline $2 / 3$ positive & 15 & 11.6 & 2 & 5.7 & 3 & 6.8 & 10 & 25.0 & 0 & 0.0 \\
\hline $3 / 3$ positive & 70 & 54.3 & 27 & 77.1 & 22 & 50.0 & 21 & 52.5 & 0 & 0.0 \\
\hline \multicolumn{11}{|c|}{ (B) Visual survey-based detectability } \\
\hline Visual survey & 129 & & 35 & & 44 & & 40 & & 10 & \\
\hline Presence & 30 & 23.3 & 6 & 17.1 & 10 & 22.7 & 14 & 35.0 & 0 & 0.0 \\
\hline
\end{tabular}



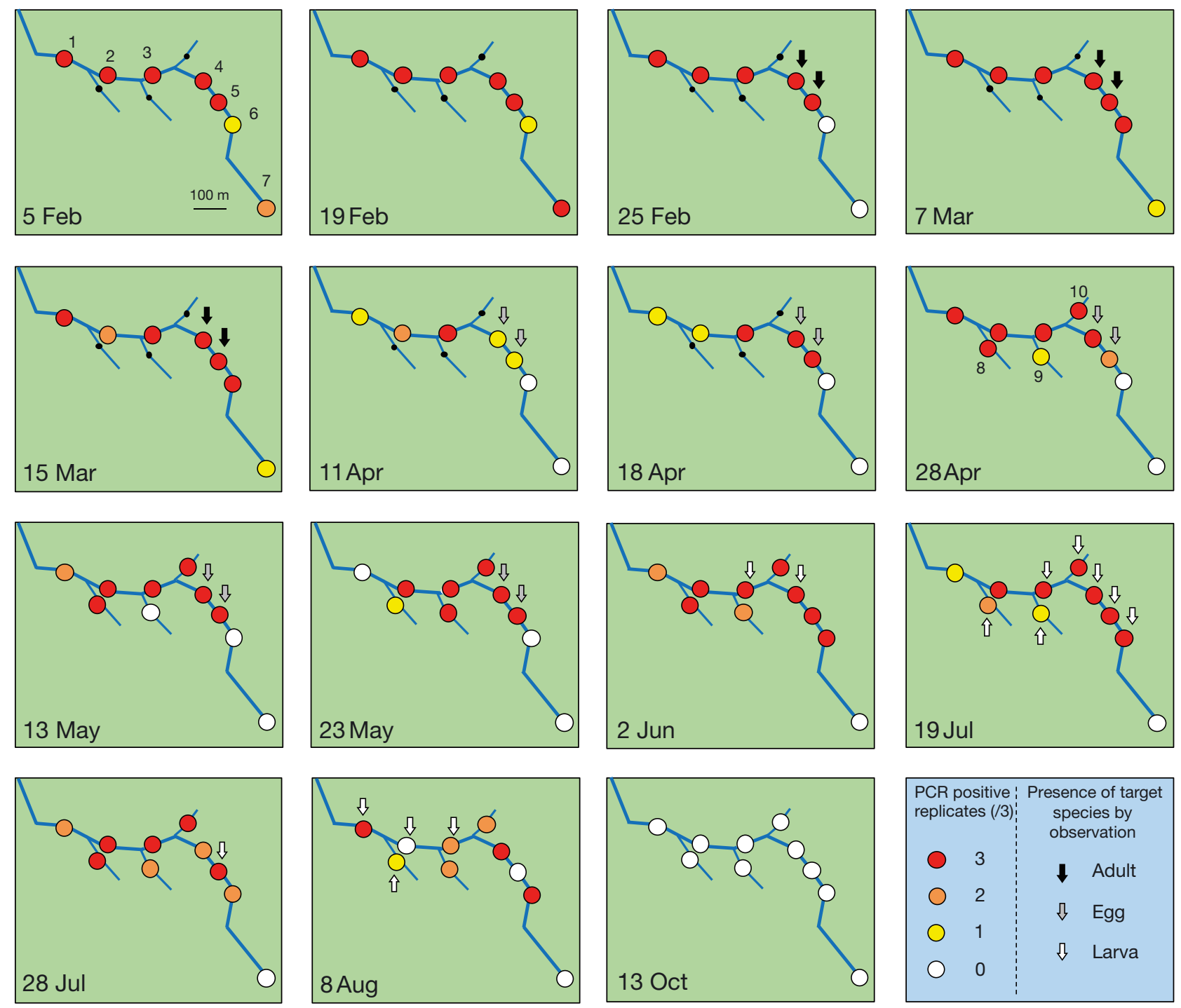

Fig. 3. Results of PCR positive rates of Hida salamander eDNA at each sampling site on each sampling day. The number of positive PCR replicates is indicated by the color of circles: red (3/3) to white (0/3). Sites at which we visually confirmed the presence of target species are indicated by arrows (adult: black; egg: gray; larva: white). Note that water sampling at the tributaries (Stns 8 to 10) began on 28 April 2016, and Stns 8 to 10 are shown as black dots until the sampling day

sequences. Moreover, all water samples showed $\Delta C_{\mathrm{t}}$ values less than 2 (Table S5 in Supplement 1), thus we considered that PCR inhibition in water samples can be neglected throughout the present study.

\subsection{Multi-scale site occupancy modeling}

The site occupancy probabilities of Hida salamander eDNA were estimated in the surveyed stream. The most supported models included the presence by visual surveys, water temperature, and $\mathrm{pH}$ for the egg period and EC for the larval period in the sitelevel probability $\Psi$, and included water temperature for the reproductive and egg periods in the samplelevel probability $\theta$ (Table 3 ; Table S6 in Supplement 1). The site-level occurrence probabilities of target eDNA tended to be higher in the presence of the species, and with higher temperature and $\mathrm{pH}$, and the sample-level occurrence probabilities tended to be higher at low temperatures, although the uncertainties of these factors were relatively high (i.e. $95 \%$ credible intervals [CI] of both variables encompassed zero) (Table 3). The mean site-level occupancy probabilities of target eDNA based on the most supported models were 0.9150 for the reproductive period, 0.8129 for the egg period, and 0.8598 for the larval period (Table S7 in Supplement 1). 
Table 3. The best-supported models for estimating the site occupancy probability of Hida salamander eDNA during each period, showing the posterior median and $95 \%$ CI of each parameter. The parameters $\beta, \alpha$, and $\delta$ represent the Bayesian estimates of site-level occurrence probability $\Psi$, sample-level occurrence probability $\theta$, and PCR replicate-level detection probability $\rho$, respectively. The terms visual, temp, and EC refer to visual survey, water temperature, and electrical conductivity, respectively. Note that the dataset for the post-larval period was excluded from analysis (see Section 2.4 for details)

\begin{tabular}{|c|c|c|c|}
\hline Period & Model & Parameter & Median (95\% CI) \\
\hline \multirow[t]{4}{*}{ Reproductive } & $\Psi(.) \theta($ temp) $\rho()$. & $\beta$ (intercept) & $1.372(0.332,2.692)$ \\
\hline & & $\alpha$ (intercept) & $1.565(0.960,2.339)$ \\
\hline & & $\alpha($ temp) & $-0.335(-1.099,0.321)$ \\
\hline & & $\delta$ (intercept) & $1.242(0.912,1.586)$ \\
\hline \multirow[t]{7}{*}{ Egg } & $\begin{array}{l}\Psi(\text { visual }+ \text { temp }+p H) \\
\theta(\text { temp }) \rho(.)\end{array}$ & $\beta$ (intercept) & $1.037(0.297,2.222)$ \\
\hline & & $\beta$ (visual) & $0.480(-0.643,1.815)$ \\
\hline & & $\beta$ (temp) & $0.022(-0.608,1.246)$ \\
\hline & & $\beta(\mathrm{pH})$ & $0.348(-0.675,1.683)$ \\
\hline & & $\alpha$ (intercept) & $1.522(0.849,2.330)$ \\
\hline & & $\alpha($ temp) & $-0.487(-1.401,0.362)$ \\
\hline & & $\delta$ (intercept) & $0.895(0.600,1.194)$ \\
\hline \multirow[t]{4}{*}{ Larval } & $\Psi(\mathrm{EC}) \theta(.) \rho()$. & $\beta$ (intercept) & $1.124(0.275,2.158)$ \\
\hline & & $\beta(\mathrm{EC})$ & $-0.277(-1.182,0.700)$ \\
\hline & & $\alpha$ (intercept) & $1.494(0.912,2.270)$ \\
\hline & & $\delta$ (intercept) & $0.977(0.683,1.274)$ \\
\hline
\end{tabular}

\section{DISCUSSION}

The present study monitored the seasonal distribution of Hida salamander in a stream using eDNA analysis that combined genus-specific primers with a species-specific probe, which outperformed the detectability by visual surveys under conditions in which the survey efforts in the field were comparable. In addition, multi-scale occupancy modeling enabled us to estimate the site occupancy probability of target eDNA based on the most supported model, and evaluate the effects of environmental factors on the target eDNA at each hierarchical level $(\Psi, \theta$, and $\rho)$. These findings support those of previous studies showing that eDNA analysis allowed the effective assessment of amphibian distributions. For example, Spear et al. (2015) have also reported that the concentration of hellbender Cryptobranchus alleganiensis eDNA increased during the September breeding period, although they did not estimate the site occupancy probability of the target eDNA. In contrast, in the present study, we took the imperfect detection with false negative into account by estimating eDNA occupancy probability, and assigned each sampling day to 1 of 4 periods (reproductive, egg, larval, and post-larval), based not only on the findings of previous studies but also on our visual surveys, which will strengthen the validity of the definition of each period. Therefore, as far as we know, this is the first study estimating the detection and site occupancy probability of amphibian eDNA during their reproductive period and before and after incubation in water.

In common with numerous other amphibians, the ecology and life history of the Hida salamander are yet to be sufficiently well described, owing to its rarity and difficulties in conducting appropriate surveillance. On the basis of very limited available literature, the Hida salamander inhabits and breeds in the lotic environment, their egg incubation requires approximately $1 \mathrm{mo}$, metamorphosis occurs between late July and late September, and no larvae are found in the water after October, although these descriptions are based on very rough estimations (Hayase \& Yamane 1989, Misawa \& Matsui 1997). In the present study, we found that the seasonal distribution of Hida salamander based on eDNA analysis is generally consistent with these previous descriptions. Target eDNA was never detected at Stn 7 in the egg to post-larval periods nor at any site in October (i.e. post-larval period) (Fig. 3). Stn 7 (the headwater of the stream) is a lentic environment, and the target species would not constantly use this site, possibly with the exception of the temporary movement of adults. Thus, the eDNA detection at Stn 7 during the reproductive period might represent such an ecology of the target species. In addition, although the presence of larvae was confirmed at several sites on 8 August, the species was never found at any site on 13 October. These results show that the signal of target eDNA can sensitively provide quantitative information on spatiotemporal ecology, such as the salamander's reproductive and seasonal activity. On the basis of our study, it appears likely that the species reproduces from February to March, then incubates the eggs for $1 \mathrm{mo}$, and, subsequent to metamorphosis, the juveniles in the surveyed stream were able to make the transition to terrestrial habitats during October at the latest.

The detection rate of Hida salamander eDNA was the highest in the reproductive period, despite the relatively low detection rate by visual surveys (Table 2). Some studies have suggested that the promotion of 
eDNA production is due to reproductive activity, such as spawning and male-male competition (Spear et al. 2015, Bylemans et al. 2017, Takahashi et al. 2018), and the results of the present study supported these indications. In the reproductive and egg periods, the presence of adults and eggs were visually confirmed only at Stns 4 and 5 (Fig. 3), while target eDNA was detected at the sites downstream (Stns 1 to 3). As there is no way of knowing whether this reflected (i) the presence of target species estimated by eDNA analysis in the site without visual detection, or (ii) the false-positive detection of target eDNA due to its downstream transport, we would need to exercise caution in interpreting the detection of target eDNA at Stns 1 to 3, particularly during this period, considering the increase in eDNA release due to reproductive activity. Despite the recent increase in studies focusing on eDNA transport (Deiner \& Altermatt 2014, Jane et al. 2015, Jerde et al. 2016, Wilcox et al. 2016, Fremier et al. 2019, Laporte et al. 2020), it remains unclear as to how far aqueous eDNA might be transported downstream and how environmental factors might affect eDNA transport. In addition, we unfortunately did not measure any hydrogeographic parameters (e.g. flow velocity, water depth, type of substrate) in the studied stream, and thus any valid assessment of the transport of target eDNA in the present study would be limited. eDNA could be transported further downstream in streams with greater flow velocity, whereas the false-positive detection of eDNA might be less frequent at sites further downstream due to its dilution in water and absorption by sediment. Consequently, further studies in which a range of hydrogeographic parameters are assessed will be necessary to gain a better understanding of the transport and diffusion of aqueous eDNA, and to enable inference of the spatial scale over which target eDNA signals can be detected at sampling sites.

It should be noted that the amounts of eDNA produced from the eggs of the Japanese eel Anguilla japonica (Takeuchi et al. 2019) and Siberian salamander Salamandrella keyserlingii (Takeshita et al. 2020) are considerably smaller than those produced by the corresponding adults and larvae. Thus, the eDNA released from eggs might be less likely to be detected downstream compared to that released from adults and larvae. Further study would be needed to detect the differences in eDNA production among different taxa and different developmental stages of the same species.

Multi-scale site occupancy modeling of the target eDNA resulted in some implications of the different effects of environmental factors on the presence of salamander eDNA during different periods. In the larval period, EC tended to negatively affect the sitelevel eDNA occurrence probability $\Psi$ (Table 3); salamander eDNA occurred less frequently at sites with higher EC values. EC is an index of the water quality, and higher values usually negatively impact the reproductive success of aquatic species (Horne \& Dunson 1994), which would thus suppress the detectability of target eDNA in the stream. Some studies have previously shown the negative relationships between EC and detectability of fish and amphibian eDNA (Pitt et al. 2017, Jo et al. 2020), which support the findings of the present study. Such an effect might be particularly pronounced in the case of larval salamanders owing to their chemical intolerance. During the reproductive and egg periods, higher water temperatures tended to negatively affect the sample-level eDNA occurrence probability $\theta$ (i.e. salamander eDNA was collected less frequently even if the eDNA was present at the site when the water temperature was higher). This may be due to the decrease in eDNA persistence at higher temperatures (Strickler et al. 2015, Jo et al. 2019). Nevertheless, the parameters estimated in the occupancy modeling have relatively high variance, which is probably attributable to the relatively small sample size and number of replicates in the present study, and the effect of environmental factors on the species occurrence probabilities were not directly confirmed here. Further study would be needed to examine whether the positive/negative effects of these factors on eDNA occurrence in this study represent the impact on the species occurrences.

Although we assessed the effect of EC on the sitelevel occupancy probability $\Psi$, we did not consider the effect of EC on the PCR replicate-level detection probability $\rho$ in occupancy modeling. This was because EC values were very low throughout the study period and actually we confirmed no PCR inhibition in water samples with relatively high EC values. Indeed, in this study, we were able to detect target eDNA in water samples with relatively high levels of

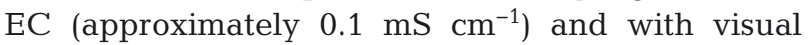
observation of target species (see Tables S1 and S4). However, some studies have found that EC can have negative effects on the PCR replicate-level detection probability (Wineland et al. 2019, Sengupta et al. 2019), although the reported EC values were considerably higher than those detected in the present study. Thus, depending on the environmental conditions, future studies should take into consideration the effects of EC on PCR detectability, and it would 
also be desirable to use PCR reagents such as Environmental Master Mix, which perform well over a wide range of $\mathrm{EC}$ values.

The present study showed the usefulness of eDNA analysis for the seasonal surveillance of salamanders, although some issues and perspectives remain to be examined. First, it would be necessary in the future to show the efficacy of the combination of genus-specific primers and a species-specific probe to detect other Hynobius spp. eDNA. This strategy could potentially target a larger number of related species than multiplex real-time PCR (Tsuji et al. 2018, Jo et al. 2020) without developing the assay for each species, and detect target eDNA with higher sensitivity than versatile nested PCR (GoFish; Stoeckle et al. 2018) due to the fluorescence probe specifically hybridizing the target PCR amplicon. Rapid and effective monitoring of Hynobius species across the country based on this approach would be required. Second, in the present study, we conducted the field survey in a single stream in a single year and used fewer replicates of water samples and PCR analyses than have hitherto been used in other eDNA studies (de Souza et al. 2016, Vörös et al. 2017, Wineland et al. 2019). Accordingly, this might have resulted in the limited inferences regarding the spatiotemporal ecology of the target species examined in this study (e.g. providing occupancy probability $\Psi$ with the site where eggs and larvae could not be present, and uncertainties of environmental factors on the target eDNA occupancy probabilities). Thus, increasing the number of water samples and PCR replicates may be important for a more precise estimation of occupancy probabilities, and this consideration should be considered in future studies. Nevertheless, the present study showed that eDNA analysis an improve the efficiency of the seasonal surveillance of threatened salamander distributions in streams without damaging the organisms and their habitat. The method used in the present study will substantially contribute to elucidating the distribution and ecology of amphibians, which is necessary for the planning of conservation activities and restoration of habitats for amphibians.

Acknowledgements. We thank Yuji Nagai (Kyoto City Construction Bureau Public Works Management Department Nishikyo Public Works Office) for assisting in the field survey. We thank Dr Yasuoki Takami (Kobe University) for the helpful comments and suggestions regarding the experimental design and interpretation of the results. This study was supported by the Environment Research and Technology Development Fund (JPMEERF20164002) of the Environmental Restoration and Conservation Agency, JSPS KAKENHI (grant numbers JP17H03735 and JP20H03326),
Grant-in-Aid for JSPS Research Fellow (grant number JP18J20979), and Chiang Mai University.

\section{LITERATURE CITED}

Barnes MA, Turner CR (2016) The ecology of environmental DNA and implications for conservation genetics. Conserv Genet 17:1-17

Beebee TJC, Griffiths RA (2005) The amphibian decline crisis: a watershed for conservation biology? Biol Conserv 125:271-285

Berger L, Speare R, Daszak P, Green DE and others (1998) Chytridiomycosis causes amphibian mortality associated with population declines in the rain forests of Australia and Central America. Proc Natl Acad Sci USA 95: 9031-9036

Bohmann K, Evans A, Gilbert MTP, Carvalho GR and others (2014) Environmental DNA for wildlife biology and biodiversity monitoring. Trends Ecol Evol 29:358-367

*B Bylemans J, Furlan EM, Hardy CM, McGuffie P, Lintermans M, Gleeson DM (2017) An environmental DNA-based method for monitoring spawning activity: a case study, using the endangered Macquarie perch (Macquaria australasica). Methods Ecol Evol 8:646-655

Bylemans J, Gleeson DM, Hardy CM, Furlan E (2018) Toward an ecoregion scale evaluation of eDNA metabarcoding primers: a case study for the freshwater fish biodiversity of the Murray-Darling Basin (Australia). Ecol Evol 8:8697-8712

Ceballos G, Ehrlich PR, Barnosky AD, García A, Pringle RM, Palmer TM (2015) Accelerated modern human-induced species losses: entering the sixth mass extinction. Sci Adv 1:e1400253

* Chen W, Ficetola GF (2019) Conditionally autoregressive models improve occupancy analyses of autocorrelated data: an example with environmental DNA. Mol Ecol Resour 19:163-175

* Darling JA, Mahon AR (2011) From molecules to management: adopting DNA-based methods for monitoring biological invasions in aquatic environments. Environ Res 111:978-988

*Daszak P, Cunningham AA, Hyatt AD (2003) Infectious disease and amphibian population declines. Divers Distrib 9:141-150

* de Souza LS, Godwin JC, Renshaw MA, Larson E (2016) Environmental DNA (eDNA) detection probability is influenced by seasonal activity of organisms. PLOS ONE 11:e0165273

*Deiner K, Altermatt F (2014) Transport distance of invertebrate environmental DNA in a natural river. PLOS ONE 9:e88786

* Deiner K, Bik HM, Mächler E, Seymour M and others (2017) Environmental DNA metabarcoding: transforming how we survey animal and plant communities. Mol Ecol 26: 5872-5895

* Dejean T, Valentini A, Miquel C, Taberlet P, Bellemain E, Miaud C (2012) Improved detection of an alien invasive species through environmental DNA barcoding: the example of the American bullfrog Lithobates catesbeianus. J Appl Ecol 49:953-959

Dodd CK (2010) Amphibian ecology and conservation: a handbook of techniques. Oxford University Press, Oxford

*Doi H, Takahara T, Minamoto T, Matsuhashi S, Uchii K, 
Yamanaka H (2015) Droplet digital polymerase chain reaction (PCR) outperforms real-time PCR in the detection of environmental DNA from an invasive fish species. Environ Sci Technol 49:5601-5608

*Dorazio RM, Erickson RA (2018) EDNAOCCUPANCY: an R package for multiscale occupancy modelling of environmental DNA data. Mol Ecol Resour 18:368-380

* Ficetola GF, Miaud C, Pompanon F, Taberlet P (2008) Species detection using environmental DNA from water samples. Biol Lett 4:423-425

Fremier AK, Strickler KM, Parzych J, Powers S, Goldberg CS (2019) Stream transport and retention of environmental DNA pulse releases in relation to hydrogeomorphic scaling factors. Environ Sci Technol 53:6640-6649

Fukumoto S, Ushimaru A, Minamoto T (2015) A basin-scale application of environmental DNA assessment for rare endemic species and closely related exotic species in rivers: a case study of giant salamanders in Japan. J Appl Ecol 52:358-365

Gotelli NJ, Colwell RK (2001) Quantifying biodiversity: procedures and pitfalls in the measurement and comparison of species richness. Ecol Lett 4:379-391

Hayase N, Yamane S (1989) Habitats and reproductive modes in Japanese hynobiid salamanders. Bull Fac Educ, Ibaraki Univ (Nat Sci) 38:85-102 (in Japanese)

Hels T, Buchwald E (2001) The effect of road kills on amphibian populations. Biol Conserv 99:331-340

Herpetological Society of Japan (2019) Standard Japanese names of amphibians and reptiles of Japan (ver. 26 Jun 2019). http://herpetology.jp/wamei/ (accessed on $27 \mathrm{Au}-$ gust 2019) (in Japanese)

Hopkins GW, Freckleton RP (2002) Declines in the numbers of amateur and professional taxonomists: implications for conservation. Anim Conserv 5:245-249

Horne MT, Dunson WA (1994) Exclusion of the Jefferson salamander, Ambystoma jeffersonianum, from some potential breeding ponds in Pennsylvania: effects of $\mathrm{pH}$, temperature, and metals on embryonic development. Arch Environ Contam Toxicol 27:323-330

*Houlahan JE, Findlay CS, Schmidt BR, Meyer AH, Kuzmin SL (2000) Quantitative evidence for global amphibian population declines. Nature 404:752

Iwai N, Yasumiba K, Takahara T (2019) Efficacy of environmental DNA to detect and quantify stream tadpoles of Odorrana splendida. R Soc Open Sci 6:181798

Jane SF, Wilcox TM, McKelvey KS, Young MK and others (2015) Distance, flow and PCR inhibition: eDNA dynamics in two headwater streams. Mol Ecol Resour 15: 216-227

* Jerde CL, Olds BP, Shogren AJ, Andruszkiewicz EA and others (2016) Influence of stream bottom substrate on retention and transport of vertebrate environmental DNA. Environ Sci Technol 50:8770-8779

Jo T, Murakami H, Yamamoto S, Masuda R, Minamoto T (2019) Effect of water temperature and fish biomass on environmental DNA shedding, degradation, and size distribution. Ecol Evol 9:1135-1146

Jo T, Fukuoka A, Uchida K, Ushimaru A, Minamoto T (2020) Multiplex real-time PCR enables the simultaneous detection of environmental DNA from freshwater fishes: a case study of three exotic and three threatened native fishes in Japan. Biol Invasions 22:455-471

Katano I, Harada K, Doi H, Souma R, Minamoto T (2017) Environmental DNA method for estimating salamander distribution in headwater streams, and a comparison of water sampling methods. PLOS ONE 12:e0176541

Kats LB, Ferrer RP (2003) Alien predators and amphibian declines: review of two decades of science and the transition to conservation. Divers Distrib 9:99-110

Kyoto Prefecture (2015) Red Data Book of Kyoto Prefecture. www.pref.kyoto.jp/kankyo/rdb/en/index.html (accessed 14 May 2020) (in Japanese)

*Laporte M, Bougas B, Côté G, Champoux O and others (2020) Caged fish experiment and hydrodynamic bidimensional modeling highlight the importance to consider 2D dispersion in fluvial environmental DNA studies. Environ DNA 2:362-372 doi: 10.1002/edn3.88

*Matsui M, Misawa Y, Nishikawa K (2009) Morphological variation in a Japanese salamander, Hynobius kimurae (Amphibia, Caudata). Zool Sci 26:87-95

Matsui M, Okawa H, Nishikawa K, Aoki G and others (2019) Systematics of the widely distributed Japanese clouded salamander, Hynobius nebulosus (Amphibia: Caudata: Hynobiidae), and its closest relatives. Curr Herpetol 38: 32-90

Minamoto T, Yamanaka H, Takahara T, Honjo MN, Kawabata Z (2012) Surveillance of fish species composition using environmental DNA. Limnology 13:193-197

Ministry of the Environment, Japan (2018) Brackish and freshwater fishes, Red list, 4th edn. www.env.go.jp/press/ files/jp/109278.pdf (in Japanese) (assessed on 2 September 2019)

* Misawa Y, Matsui M (1997) Larval life history variation in two populations of the Japanese salamander Hynobius kimurae (Amphibia, Urodela). Zool Sci 14:257-263

* Pitt AL, Shinskie JL, Tavano JJ, Hartzell SM, Delahunty T, Spear SF (2017) Decline of a giant salamander assessed with historical records, environmental DNA and multiscale habitat data. Freshw Biol 62:967-976

R Core Team (2019) R: a language and environment for statistical computing. R Foundation for Statistical Computing, Vienna

Sadinski WJ, Dunson WA (1992) A multilevel study of effects of low $\mathrm{pH}$ on amphibians of temporary ponds. J Herpetol 26:413-422

K Sakai Y, Kusakabe A, Tsuchida K, Tsuzuku Y and others (2019) Discovery of an unrecorded population of Yamato salamander (Hynobius vandenburghi) by GIS and eDNA analysis. Environ DNA 1:281-289

* Schmidt BR, Kery M, Ursenbacher S, Hyman OJ, Collins JP (2013) Site occupancy models in the analysis of environmental DNA presence/absence surveys: a case study of an emerging amphibian pathogen. Methods Ecol Evol 4: $646-653$

* Sengupta ME, Hellström M, Kariuki HC, Olsen A and others (2019) Environmental DNA for improved detection and environmental surveillance of schistosomiasis. Proc Natl Acad Sci USA 116:8931-8940

* Spear SF, Groves JD, Williams LA, Waits LP (2015) Using environmental DNA methods to improve detectability in a hellbender (Cryptobranchus alleganiensis) monitoring program. Biol Conserv 183:38-45

* Stoeckle MY, Mishu MD, Charlop-Powers Z (2018) GoFish: a versatile nested PCR strategy for environmental DNA assays for marine vertebrates. PLOS ONE 13:e0198717

* Strickler KM, Fremier AK, Goldberg CS (2015) Quantifying effects of UV-B, temperature, and $\mathrm{pH}$ on eDNA degradation in aquatic microcosms. Biol Conserv 183:85-92

Taberlet P, Coissac E, Hajibabaei M, Rieseberg LH (2012) Environmental DNA. Mol Ecol 21:1789-1793 
Takahashi MK, Meyer MJ, Mcphee C, Gaston JR, Venesky MD, Case BF (2018) Seasonal and diel signature of eastern hellbender environmental DNA. J Wildl Manag 82: 217-225

Takeshita D, Terui S, Ikeda K, MitsuzukaT, Osathanunkul M, Minamoto T (2020) Projection range of eDNA analysis in marshes: a suggestion from the Siberian salamander (Salamandrella keyserlingii) inhabiting the Kushiro marsh, Japan. PeerJ 8:e9764

Takeuchi A, Iijima T, Kakuzen W, Watanabe S and others (2019) Release of eDNA by different life history stages and during spawning activities of laboratory-reared Japanese eels for interpretation of oceanic survey data. Sci Rep 9:6074

*Thomsen PF, Willerslev E (2015) Environmental DNA — an emerging tool in conservation for monitoring past and present biodiversity. Biol Conserv 183:4-18

Tsuji S, Iguchi Y, Shibata N, Teramura I, Kitagawa T, Yamanaka H (2018) Real-time multiplex PCR for simultaneous detection of multiple species from environmental DNA: an application on two Japanese medaka species. Sci Rep 8:9138

Uchii K, Doi H, Minamoto T (2016) A novel environmental DNA approach to quantify the cryptic invasion of nonnative genotypes. Mol Ecol Resour 16:415-422

Vörös J, Márton O, Schmidt BR, Gál JT, Jelić D (2017) Surveying Europe's only cave-dwelling chordate species (Proteus anguinus) using environmental DNA. PLOS ONE 12:e0170945

Editorial responsibility: Brendan Godley, University of Exeter, Cornwall Campus, UK
Watanabe S (2010) Asymptotic equivalence of Bayes cross validation and widely applicable information criterion in singular learning theory. J Mach Learn Res 11: 3571-3594

Wells KD (2010) The ecology and behavior of amphibians. University of Chicago Press, Chicago, IL

*Wilcox TM, McKelvey KS, Young MK, Jane SF and others (2013) Robust detection of rare species using environmental DNA: the importance of primer specificity. PLOS ONE 8:e59520

*Wilcox TM, McKelvey KS, Young MK, Sepulveda AJ and others (2016) Understanding environmental DNA detection probabilities: a case study using a stream-dwelling char Salvelinus fontinalis. Biol Conserv 194:209-216

Wineland SM, Welch SM, Pauley TK, Apodaca JJ and others (2019) Using environmental DNA and occupancy modelling to identify drivers of eastern hellbender (Cryptobranchus alleganiensis alleganiensis) extirpation. Freshw Biol 64:208-221

*Wozney KM, Wilson CC (2017) Quantitative PCR multiplexes for simultaneous multispecies detection of Asian carp eDNA. J Gt Lakes Res 43:771-776

Yamanaka H, Minamoto T, Matsuura J, Sakurai S and others (2017) A simple method for preserving environmental DNA in water samples at ambient temperature by addition of cationic surfactant. Limnology 18:233-241

* Young BE, Lips KR, Reaser JK, Ibáñez R and others (2001) Population declines and priorities for amphibian conservation in Latin America. Conserv Biol 15:1213-1223

Submitted: March 17, 2020; Accepted: August 31, 2020 Proofs received from author(s): November 2, 2020 